\title{
A study of customer relationship management (CRM) on apparel European Web sites
}

\author{
J. Lawler ${ }^{1}$, P. Vandepeutte ${ }^{2}$ \& D. Anderson ${ }^{1}$ \\ ${ }^{I}$ Pace University, USA \\ ${ }^{2}$ University of Mons-Hainaut, Belgium
}

\begin{abstract}
This study explores customer relationship management (CRM) on the Web sites of apparel firms in Europe. Customer relationship management and data mining are critical differentials that enable competitive edge for firms focused on increasing customer market share. Though investment in marketing, sales and service innovation can be constrained due to economic and cultural considerations, the initial analysis of the study indicates common European consumer apparel sites enable higher content depth, navigational context and help, consumer communication, and commerce efficiency. However, the study concurrently indicates lower customer customization and mining, lifestyle connection and marketing, and consumer community interaction, on the sites. The analysis, conducted as an assignment by adult students at a leading European university, contributes insight into the limitation of customer relationship management and data mining investment on the Web. This study will benefit practitioners and researchers who continue to evaluate innovation in technology on the European Web.
\end{abstract}

Keywords: apparel industry, business-to-consumer (b2c), e-commerce in Europe, customer relationship management (CRM), data mining on the Web, European Union.

\section{Background}

The World Wide Web is an important consideration in the growth of business firms in America. From its inception, the Web has initiated unprecedented change in enabling improved channels of business with customers (Porter [1]). From customer-centric channels to customer-focused processes, firms have 
employed innovation in customer relationship management (CRM) to enhance their business-to-consumer (B2C) models (Seybold [2]). New features for marketing, sales and service on the Web have contributed benefits to customers and firms in America (Peterson et al. [3]). The design of feature functionality of customer relationship management on a Web site is important in the effectiveness of the site in influencing the attitude and the behavior of a customer towards the firm.

The effectiveness of customer relationship management on a Web site is differentiated in the experience of the customer on the site (Novak et al. [4] and Nielsen [5]). Experience may be a crucial element in the intention of the customer to buy on that site. Experience is influenced by dynamic interaction between the customer and the customer-oriented firm (Webb et al. [6]). Important in the interaction is the influence of the customer interface on future customer relationship (Rayport and Jaworski [7] and Haubl and Trifts [8]). Implementation of infinite designs of an interface on pages of the Web site is a complex and constant challenge for designers of sites (Singh et al. [9]). Firms continue to be challenged in customer interface, in order to have competitively distinguishable customer relationship management on the Web.

The expectations of customers continue to escalate in customized and personalized interfaces on the Web (Rust and Lemon [10] and Bolton and Lemon [11]). Personalizing and convenience customers demand experiences of interpersonal gratification and service from a Web site (Fitzsimmons and Fitzsimmons [12]). Budget justification of customized innovation in functionality of customer relationship management and data mining is, however, difficult in firms in America, due to dissatisfaction from failures in implementation of the technologies and to economic issues. Though customer relationship management is important in influencing customers (Lawler [13]), the effectiveness of innovation on the Web sites in financially limited firms is not clearly evaluated in academic literature. Given the global domain of the Web, an exploratory study of customer relationship management in industry, at an international level and initiating in Europe, may be helpful in introducing designs for intelligent investment in the technologies.

\section{Introduction}

The World Wide Web is an important factor in the growth of firms in Europe as in America (European Commission [14]). The number of consumers on the Web in Europe is approximately 231 million in 2004, an increase of $124 \%$ from 2000 , for $28 \%$ of international consumers, in contrast to 222 million, $106 \%$ and $27 \%$ in North America (Internet World Statistics [15]). Retail consumer revenue in Western Europe approximated 69 billion euros in 2004, and sales are estimated to grow to 274 billion in 2008 [16]. Though consumer sales of larger firms on the Web approximated 5\% of all revenue sources in the European Union in 2003 [14], in contrast to 8\% in America in 2005 (Gagnier [17]), consumers on the Web in Europe are growing to be mainstream customers of this buying channel. The importance of e-Business on the Web in the European Union is indicated in 
industry indices that include the retail industry [14], which, in apparel firms of this industry, may benefit from customer relationship management on the Web.

The inclusion of customer relationship management on European retail sites, such as apparel clothing sites, indicates conformance to basic design feature functionality of content, context of help, communication, and commerce (Rayport and Jaworski [18]) on the sites, if not implied initial investment in customer relationship management technologies. Not clear is an indication of advanced design functionality of community, connection and customization [18], and data mining, on the European sites. Firms in Western Europe (Friedman [19]) may be hesitant in fully investing in customer relationship management design on their Web sites (Ferguson et al. [20], Markillie [21] and Zhu et al. [22]).

To help in increased buying on apparel sites, firms have to differentiate in their design of experience (Pullman and Gross [23] and Winter et al. [24]). Differentiation in encountering a home page of an apparel Web site, searching and choosing clothing from a catalog on the site, ordering and paying for the clothing, and contacting customer service if needed enables experience in apparel shopping on the Web. Experience is not infrequently abysmal (Betts [25] and Underhill [26]). Innovation in the design of the apparel buying experience is indicated to give an edge to apparel Web sites (Kontzer [27]). Further differentiation in experience and in interface on the site may be needed in advanced functionality of technology.

Studies indicate the functionality of personalization and customization of apparel Web sites as important in the differentiation of these sites (Drogan and Hsu [28]). Customization allows consumers to alter choices and configurations of clothing during shopping on the Web site (Schrage [29]). Examples of customization in the apparel industry are www.landsend.com (Turban et al. [30]), www.gap.com, www.nike.com, and www.wemadebyme.com (Piller [31]). Personalization allows firms to change catalog configurations of clothing and accessory offerings to customers on the Web, based on explicit or implicit buying preferences during the shopping (Keenan [32]). An example is www.jcrew.com. Personalization and customization mining technologies are indicated to give an improved edge to the apparel Web site Roberts [33].

This study analyzes content, context, communication and commerce, and community, connection and customization [18], as features of customer relationship management, defined as important in the differentiation of experience on apparel European Web sites. This functionality forms an initial base for studying the extent and effectiveness of current customer management and data mining on the sites. The importance of the full functionality of customer relationship management technologies on European sites is not clear in academic studies.

\section{Features of apparel clothing sites on the Web}

The features of customer management, on the sites of apparel European firms analyzed in the study, are elements of e-Commerce customer interface 
influencing effectiveness of relationship on a Web site. Rayport and Jaworski define these elements as content, context, communication, community, connection, customization and commerce [18], enhanced in this study of clothing sites to include the following constructs:

- Content, defined as depth of information in arrival clothing, consumer buying guides, organized, relevant and searchable seasonal clothing inventories of stores, consumer designed dress models, fashion mannequin models, multi-dimensional multimedia pictures, representations and simulations of non-mannequin models, and videos;

- Context, depth of comfort in color moods and ease of layout in fast and intuitive navigation in European languages, text help, hyperlinks, mouse over text, and search systems;

- Communication, degree of dialogue in service and sales chats, e-mail links, e-mail newsletters, frequently asked questions, instant messaging, live Web help, hot-line telephone, telephony, and wireless;

- Community, degree of consumer interaction in firm branded consumer bulletin boards, blog chats, Webcast events, forums, entertainment event sponsorships, games, help from other consumers, consumer product reviews, and pop-up surveys;

- Connection, degree of connection to affiliated lifestyle and marketing merchant sites on the Web;

- Customization, degree of explicit and implicit customization and mining in personalization of customer configurations of dress models and clothing choices, contextual and affinity marketing of clothing, recommendations in clothing and accessory selections and in sartorial lifestyle services, and special Webmercials; and

- Commerce, extent and speed of commercial interaction, choices of delivery, discounts, special offers, one-click express checkouts, methods of payment, customer order tracking, privacy and security services, and tools and transaction on wireless.

These constructs consist of advanced and basic functionality on the Web that enable customer relationship management, defined in this study to be the following:

- $\quad$ Customer Relationship Management (CRM) - strategy of optimizing the processes of apparel firms, which enables the marketing, sales and service of clothing, through innovation and data mining of integrated customer channels, including that of the functionality of the Web, and which enables customer loyalty and apparel firm profitability.

\section{Focus of study}

The focus of this study is to analyze the current effectiveness in innovation of customer relationship management on apparel European Web sites. The study attempts to demonstrate the extent of features of data mining and customer relationship management innovation on the sites, in generic contrast to American sites. Though guidelines in the design of Web sites abound in practitioner and 
scholarly studies, this study is focused on exploring functionality that facilitates relationship on apparel European sites and on furnishing a future framework for intelligent investment in customer relationship management technologies on the Web.

\section{Research methodology}

The research methodology of the study consisted of a content analysis of a sample of on-line apparel firms in Europe, in five iterative stages of analysis. In stage 1, 150 different clothing sites were chosen by 40 adult postgraduate, graduate and undergraduate business marketing students, as an assignment in an e-Business Concepts and Applications course, at the University of Mons-Hainaut in Belgium. The students chose the 150 sites based on consumer commonality of the sites on the Western European Web.

In stage 2, 10 clothing sites from the 150 in stage 1 were chosen for analysis by the instructors. The instructors are the authors of this study. They chose Dutch, English, French, German and Spanish language sites, consisting of abound, bonaparte, bonprix, cyrillus, haburi, laredoute, mangoshop, mexx, somewhere, and 3suisses, in e-Commerce European traditionalist countries (Ferguson et al. [34]). The instructors chose the 10 sites based on earlier frequency of choice, functionality of e-Commerce, and diversity of language on the sites. The students were adequately conversant in languages to analyze the 10 sites. These sites were analyzed anonymously and independently in the spring 2005 semester of the course.

The 40 students who analyzed the 10 sites were knowledgeable consumer subjects. Demographics of the students indicate that their average age was 24 years, they were employed part-time (30\%) in local industry, and they included female $(45 \%)$ and male $(55 \%)$ subjects. They were frequent and intelligent consumers of the Web (12.2 hours a week on the Web in 2005 for 5.5 years, with higher broadband, cable and internal networking connectivity than in America). The findings, however, of an analysis that includes such a small sample of students may not be generalized to a larger population in European society without caution. Studies nevertheless indicate the appropriateness of students in analyses of on-line research and shopping, inasmuch as students are perceived as mature consumers (McKnight et al. [35] and wired on the Web Bellman et al. [36]). The students in this study of apparel European Web sites were enthusiastic and realistic subjects.

The 10 sites were analyzed in stage 2 for their potential relationship effectiveness in the constructs of content, context, communication, community, connection, customization, and commerce, applying a three-point scale of 3 =high, 2 = intermediate, and $1=$ low functionality in technologies, as illustrated in Figure 1. The constructs were defined from a checklist instrument of the 69 functions indicated in the earlier Features of Apparel Clothing Sites on the Web section of this study, and the functions spanned depth of content to transaction on wireless. The students were instructed in the constructs during lectures in the course. 
In stage 3 of the study, the data from stage 2 was collected from the students and analyzed in summer - fall 2005 by the authors, in order to determine construct mean scores and statistical significance. This analysis, in the next section, included unadjusted averaging that was considered better than an advanced analysis, due to ease of interpretation and robustness. Though averaging limited the degrees of freedom available for analysis, adequate strength was available to distinguish between the constructs.

(In stage 4 of an advanced study, the evolving sites in stage 2, with a larger sample of other apparel clothing sites where feasible, will be analyzed in the course, in fall 2005 - summer 2006. In stage 5, a sample of the sites in stages 4 and 2 will be analyzed in case studies of customer relationship management strategies of the industry managers of the sites, in summer - winter 2006.)

\section{Analysis of apparel clothing sites on the Web}

The analysis from stages 2 and 3 indicated that most of the apparel Web sites in the sample of the study has higher content, context, communication and commerce, but lower customization, connection and community. That is, content (210 [score]), context (200), communication (175) and commerce (172) constructs as a group are high in functionality; customization (55), connection (86) and community (101) as a group are low, and customization is the lowest (55), as summarized in Table 1. From the analysis, female students $(45 \%)$ evaluated the sites lower than the male students (55\%), as the female students are inclined to buy higher in off-line stores but not on on-line sites on the Web.

The interpretation of the results in Table 1 is that clothing sites in the sample are effective in commercial interaction, facility for dialogue, guiding the consumer, and in information. Such functionality enables the initiation of relationship. The cultivation of the consumer as a customer is not effective in limited functionality of consumer-to-consumer and lifestyle merchant interaction. Customization and intelligent personalization of recommended products and services by consumer or customer types are not evident on the sites. Mining of the customer is not clear from the sites or from furnished documentation of the stores.

The effectiveness of customer relationship management is elusive on the sites in the initial study. In the best of the sites, the focus of investment is on colorful content depth, context navigation, and commerce functionality. In the worst of the sites, investment is focused on faster commerce functionality. None of the sites excel in customer relationship management, as contrasted to the best of American apparel clothing sites, as in www.jcrew.com or www.landsend.com. The study from stages 2 and 3 indicate lower potential for relationship.

(The importance of the constructs in customer relationship management, including community, connectivity and customization, will be analyzed further in stages 4 and 5 of the advanced study. Though the results of the expanded study will not be final until completion of stage 5, in winter 2006, the scores of stages 3 and 2 of this study are helpful in introducing implications in the current effectiveness in innovation and investment in customer relationship management and data mining on the apparel European Web sites.) 
Table 1: $\quad$ Summary analysis of apparel European clothing sites on the Web*.

\begin{tabular}{|c|c|c|c|c|c|}
\hline \multicolumn{6}{|c|}{$\begin{array}{l}\text { Apparel European Clothing Sites ** } \\
\text { Effectiveness in Functionality }\end{array}$} \\
\hline & Constructs & $\begin{array}{l}\text { High } \\
\text { Score } 1\end{array}$ & $\begin{array}{l}\text { Intermediate } \\
\text { Score 2 }\end{array}$ & $\begin{array}{l}\text { Low } \\
\text { Score } 3\end{array}$ & $\begin{array}{l}\text { Analysis } \\
\text { Completion } \\
\text { Percentage } \\
* * *\end{array}$ \\
\hline $\mathrm{C} 1$ & \begin{tabular}{|l|} 
Content \\
\end{tabular} & $210(52.5 \%)$ & \begin{tabular}{|l|l}
$151(37.8 \%)$ \\
\end{tabular} & $\begin{array}{ll}38 & (9.5 \%) \\
\end{array}$ & $99.80 \%$ \\
\hline $\mathrm{C} 2$ & \begin{tabular}{|l|} 
Context \\
\end{tabular} & $200(50.0 \%)$ & \begin{tabular}{|l|}
$157(39.3 \%)$ \\
\end{tabular} & $43 \quad(10.8 \%)$ & $100 \%$ \\
\hline $\mathrm{C} 3$ & Communication & $175(43.8 \%)$ & \begin{tabular}{|l|}
$159(39.8 \%)$ \\
\end{tabular} & $\begin{array}{ll}65 & (16.3 \%)\end{array}$ & $99.80 \%$ \\
\hline $\mathrm{C} 4$ & Community & $101(25.3 \%)$ & \begin{tabular}{|l|}
$112(28.0 \%)$ \\
\end{tabular} & $185(46.3 \%)$ & $99.50 \%$ \\
\hline $\mathrm{C} 5$ & Connection & $86 \quad(21.5 \%)$ & $97 \quad(24.3 \%)$ & $215(53.8 \%)$ & $99.50 \%$ \\
\hline C6 & Customization & $55(13.8 \%)$ & \begin{tabular}{|l|}
$147(36.8 \%)$ \\
\end{tabular} & $198(49.5 \%)$ & $100 \%$ \\
\hline C7 & Commerce & $172(43.0 \%)$ & \begin{tabular}{|l|}
$136(34.0 \%)$ \\
\end{tabular} & $85(21.3 \%)$ & $98.30 \%$ \\
\hline
\end{tabular}

* n=10 Apparel European Firm Sites x 40 Consumer Students

** Detailed Analysis of Specific Sites Available upon Request of Authors

*** Limited Number of Non-Analysis Completions Due to Language Limitations of a Few Students

(Construct Source: Rayport and Jaworski [18]).

\section{Implications}

The immediate implication of this study is the clear indication of higher innovation in the fundamental customer relationship management functionality of content, context, communication and commerce on the European sites. Results indicated conformance to design importance noted in scholarly papers (Koufaris et al. [37] and Kim and Stoel [38]). Firms analyzed in the study have effectively invested in initially favorable experiences for consumers.

The next implication is the contrasted indication of limited differentiation and lower innovation in the advanced customer relationship management functionality of customization and data mining. The importance of customer centric contextual and customized marketing, sales and service, and of customer demand, is noted in scholarly studies (Luo and Seyedian [39], and Sheth et al. [40] and Sharma and Sheth [41]). The results of this study however indicated limited investment in back-end and front-end functionality of personalization and customization, on the analyzed clothing sites. Such results are consistent with current European practitioner studies (Piller [42]), but are impacted by European Union Directive 2002/58/EC, Directive on Privacy and Electronic Communications, informational privacy regulations (European Parliament [43]). These regulations are stricter than those in America (Baumer et al. [44]). The results are further impacted by generic factors in security and trust. Some studies imply, if not indicate, hesitancy in continued investment in customization of sites on the Web (Piller [45] and Gonsalves [46]). Interfaces on sites, however, have to be beyond fundamental functionality of commerce, communication, context and content, in order to have an edge (Griffith et al. [47] and Jukic et al. [48]). Firms initiating innovation may have to consider effective 
incremental exploitation of advanced customer relationship management technologies.

Implications of the study include indication of lower innovation in community and connection functionality. Results indicated low investment in connection of the clothing sites to affinity product sites and in inclusion of consumer evangelistic communities of interest on the analyzed sites. Such functionality of sharing is frequent on the best of American apparel sites on the Web, as in the Converse Gallery site in the United States. The importance of this functionality is noted in studies (Zwass [49]). European firms may have to consider impact and incremental investment, subject to cultural factors and to business strategies.

Further implications include implied indication of benefits of considering improved inclusion of e-Commerce European governmental and industrial initiatives, in helping firms in their strategies. Such initiatives as those of the European Commission and the e-Europe Action Plan [20] in entrepreneurship have to be increased to stimulate firms in innovation. The partnership support of governmental and industrial organizations is important in the investment of skills and technologies.

The final implication of the initial study is the indication of the benefits of including students as consumers (Alavi et al. [50]). Though their number was a controlled and non-random small sample, the Belgian students at the University of Mons-Hainaut were dedicated, eager and fashion interested subjects. Motivation by the instructors was not an issue. These students were clearly realistic subjects, wired in the technologies of the Web, and future customers of clothing Web sites. Lastly, the study was helped in insight by two of the authors as instructors in e-Commerce, at the School of Computer Science and Information Systems at Pace University, in America and the other as an e-Business instructor, at the Warocque Research Center of the University of Mons-Hainaut, in Europe.

\section{Limitations and opportunities in research}

This study furnishes a framework for evaluating customer relationship management on European Web sites, as the implications of the small sample of only one industry cannot be generalized and have to be interpreted cautiously. Not only a larger, more natural and random sample selection of firm sites and of bona fide consumer subjects, but also of sites and of subjects in other Western and Eastern European languages and societies, have to be considered for analysis of the apparel industry on the Web. Expanded empirical investigation of results will be helpful in insuring creditability of future planned studies.

\section{Conclusion}

The initial study indicates that popular apparel firms in Europe are focused less on advanced customization and mining, lifestyle connection and marketing, and community interaction, and more on fundamental commerce efficiency, communication, context and help, and content depth functionality, resulting in 
limited customer relationship management on the Web sites. To compete more effectively for increased market share, the clothing firms may need to further invest in innovation on their sites. Further research is needed to analyze the customer relationship management strategies and the data mining technologies of apparel European firms on the Web.

\section{Acknowledgements}

The authors are grateful to Bernard Lux, President of the University of MonsHainaut, and to the National Fund for Scientific Research, for financial support of this study, in 2006 and 2005.

\section{References}

[1] Porter, M. E., Strategy and the internet. Harvard Business Review, 79(3), March, pp. 62-78, 2001.

[2] Seybold, P., The Customer Revolution, Crown: New York, pp. 203-227,248- 279, 2001.

[3] Peterson, R.A., Balasubramanian, S. \& Bronnenberg, B.J., Exploring the implications of the internet for consumer marketing. Journal of the Academy of Marketing Science, 25(4), pp. 329-346, 1997.

[4] Novak, T.P., Hoffman, D.L. \& Yung, Y-F., Measuring the customer experience in on-line environments: a structural modeling approach. Marketing Science, 19, Winter, pp. 22-42, 2000.

[5] Nielsen, J., User interface directions for the web. Communications of the $A C M, 42(1)$, pp. 65-72, 1999.

[6] Webb, D., Webster, C. \& Krepapa, A., An exploration of the meaning and outcomes of a customer-defined market orientation. Journal of Business Research, 48(2), pp. 101-112, 2000.

[7] Rayport, J. F. \& Jaworski, B. J., Best Face Forward: Why Companies Must Improve Their Service Interfaces with Customers, Harvard Business School Press: Boston, Massachusetts, pp. xix, 19, 67, 83, 85, 2005.

[8] Haubl, G. \& Trifts, V., Consumer decision-making in on-line shopper environments: the effects of interactive decision aids. Marketing Science, 19(1), pp. 4-21, 2000.

[9] Singh, S. N., Dalal, N. \& Spears, N., Understanding web home page perception. European Journal of Information Systems, 14(3), September, pp. 288-302, 2005.

[10] Rust, R. T. \& Lemon, K. N., E-service and the consumer. International Journal of Electronic Commerce, 5(3), Spring, p. 90, 2001.

[11] Bolton, R.N. \& Lemon, K.N., A dynamic model of customers' usage of services: usage as an antecedent and consequence of satisfaction. Journal of Marketing Research, 36, May, pp. 171-186, 1999.

[12] Fitzsimmons, J. A. \& Fitzsimmons, M. J., Service Management: Operations, Strategy and Information Technology, McGraw Hill Irwin: New York, pp. 105-106, 2004. 
[13] Lawler, J. P., Customer loyalty and privacy on the web. Journal of Internet Commerce, 2(1), Summer, pp. 89-105, 2003.

[14] European Commission, A Pocketbook of e-Business Indicators: A Portrait of e- Business in 10 Sectors of the European Union Economy, www.ebusiness-watch.org, April, pp. 6, 8, 24, 25, 54, 2004.

[15] Internet World Statistics: Usage and Population Statistics, Internet Usage Statistics - The Big Picture, www.internetworldstats.com, 3 December, p. 1, 2004.

[16] http://www.journaldunet.com/cc/04_ecommerce/ecom_marche_eu.shtml, 2 August, 2005.

[17] Gagnier, M., Why e-retailers are e-lated. Business Week, 6 June, p. 48, 2005.

[18] Rayport, J. F. \& Jaworski, B. J., Introduction to e-Commerce, McGraw Hill Irwin MarketspaceU: New York, pp. 151-182, 2004.

[19] Friedman, T. L., End of the rainbow. The New York Times, Times Digest, Opinion, 29 June, p. 8, 2005.

[20] Ferguson, G. T., O’Mahony, R., Padmore, L., Saynor, K., Sinclair, A., Smith, M. D.B. \& Yates, M., Fourth Annual Accenture Survey of European e-Commerce, http://www.accenture.com/eEurope2001, August, pp. 52, 55, 57, 77,81,82,89, 2001.

[21] Markillie, P., Power at last: how the internet means the consumer really is king (and queen). The Economist, Special Report, 375(8420), 2-8 April, p. 11, 2005.

[22] Zhu, K., Kraemer, K. \& Xu, S., Electronic business adoption by European firms: a cross-country assessment of the facilitators and inhibitors. European Journal of Information Systems, 12(4), December, pp. 264-265, 2003.

[23] Pullman, M. E. \& Gross, M. A., Ability of experience design elements to elicit emotions and loyalty behaviors. Decision Sciences, 35(3), Summer, p. 553, 2004.

[24] Winter, S. J., Saunders, C. \& Hart, P., Electronic window dressing: impression management with web sites. European Journal of Information Systems, 12(4), December, pp. 311-312,319, 2003.

[25] Betts, M., Global home pages receive abysmal report cards. Computerworld, 4 July, p. 30, 2004.

[26] Underhill, P., Why We Buy: The Science of Shopping, Simon \& Schuster: London, pp. 220-223, 1999.

[27] Kontzer, T., Web sites build loyalty: retail web sites have much more value. Information Week, 24 January, p. 12, 2005.

[28] Drogan, M. \& Hsu, J., Enhancing the web customer's experience: techniques and business impacts of web personalization and customization, Proceedings of the Information Systems Education Conference (ISECON), 3424, ed. D. Colton, San Diego, California, pp. 116, 2003.

[29] Schrage, M., The next step in customization. MC Technology Marketing Intelligence, 8 August, pp. 20-21, 1999. 
[30] Turban, E., King, D., Viehland, D. \& Lee, J., Electronic Commerce 2006: A Managerial Perspective, Pearson Prentice Hall: Upper Saddle River, New Jersey, p. 89, 2006.

[31] Piller, F. T., Mass customization web links. Mass Customization \& Open Innovation News, 24 August, p. 1, 2005.

[32] Keenan, F., A mass market of one: as custom on-line ordering moves into the mainstream, web merchants learn to fine-tune their trade. Business Week, 2 December, pp. 68-72, 2002.

[33] Roberts, M. L., Internet Marketing: Integrating On-Line and Off-Line Strategies, McGraw Hill Irwin: New York, pp. 155-157, 2003.

[34] Ferguson, G. T., O’Mahony, R., Padmore, L., Saynor, K., Sinclair, A., Smith, M. D.B. \& Yates, M., Fourth Annual Accenture Survey of European e-Commerce, http://www.accenture.com/eEurope2001, August, 52, 2001.

[35] McKnight, D.H., Choudhury, V. \& Kacmar, C., Developing and validating trust measures for e-commerce: an integrative typology. Information Systems Research, 13(3), pp. 334-359, 2002.

[36] Bellman, S., Lohse, G.L. \& Johnson, E.J., Predictors of on-line buying behavior. Communications of the ACM, 42, pp. 32-38, 1999.

[37] Koufaris, M., Kambil, A. \& Labarbera, P. A., Consumer behavior in webbased commerce: an empirical study. International Journal of Electronic Commerce, 6(2), Winter, pp. 118, 133, 2001-2002.

[38] Kim, S. \& Stoel, L., Apparel retailers: web site quality dimensions and satisfaction. Journal of Retailing and Consumer Services, 11, p. 109, 2004.

[39] Luo, X. \& Seyedian, M., Contextual marketing and customer-orientation strategy for e-commerce: an empirical analysis. International Journal of Electronic Commerce, 8(2), Winter, pp. 95-97, 109, 2003-2004.

[40] Sheth, J., Sisodia, R.S. \& Sharma, A., Antecedents and consequences of the growth of customer centric marketing. Journal of Academy of Marketing Sciences, 28, Winter, pp. 55-66, 2000.

[41] Sharma, A. \& Sheth, J. N., Web-based marketing: the coming revolution in marketing thought and strategy. Journal of Business Research, 57, p. $697,2004$.

[42] Piller, F. T., Mass customization, personalization, and customer satisfaction. Mass Customization News, 7(3), November, p. 2, 2004.

[43] European Parliament, Directive 2000/31/EC of the European Parliament and of the Council. Official Journal of the European Communities, 8 June, pp. 1-16, 2000.

[44] Baumer, D. L., Earp, J. B. \& Poindexter, J.C., Internet privacy law: a comparison between the United States and the European Union. Computers \& Security, 23, p. 400-412, 2004.

[45] Piller, F. T., Reflect.com closed for business: learning from a major mass customization experiment. Mass Customization \& Open Innovation News, 23 August, p. 1, 2005. 
[46] Gonsalves, A., Personalization said to be ineffective on on-line retail sites. CMP United Business Media: TechWeb - The Business Technology Network, 14 October, pp. 1-2, 2003;

[47] Griffith, D. A., Krampf, Robert F. \& Palmer, Jonathan W., The role of interface in electronic commerce: consumer involvement with print versus on-line catalogs. International Journal of Electronic Commerce, 5(4), Summer, p. 147, 2001.

[48] Jukic, N., Jukic, B., Meamber, L. A. \& Nezlek, G., Implementing polyinstantiation as a strategy for electronic commerce customer relationship management. International Journal of Electronic Commerce, 7(2), Winter, p. 9, 2002-2003.

[49] Zwass, V., Electronic commerce and organizational innovation: aspects and opportunities. International Journal of Electronic Commerce, 7(3), Spring, p. 9, 2003.

[50] Alavi, M., Wheeler, B. \& Valacich, J., Using information technology to reengineer business education: an exploratory investigation of collaborative telelearning. MIS Quarterly, 19(3), September, pp. 293-313, 1995. 